\title{
A Suggested Model for Developing and Assessing Competence of Prospective Teachers in Faculties of Education
}

\author{
Dalal A. Alqiawi ${ }^{1, *}$ \& Sawsan M. Ezzeldin ${ }^{2}$ \\ ${ }^{1}$ Faculty of Education, Department of Curriculum and Instruction, University of Jeddah, Jeddah, Saudi Arabia \\ *Correspondence: Faculty of Education, Department of Curriculum and Instruction, University of Jeddah, Jeddah, \\ Saudi Arabia. E-mail: dalqaiawi@uj.edu.sa
}

Received: October 20, 2015

Accepted: December 3, 2015 Online Published: December 8, 2015

doi:10.5430/wje.v5n6p65

URL: http://dx.doi.org/10.5430/wje.v5n6p65

\begin{abstract}
Background: Competence assessment of teachers has long been a concern for teachers in the Faculties of Education. The decision makers have been looking for a model to assess the competence of prospective students. Tools and assessment models are used to gauge the competency of teachers in all disciplines.
\end{abstract}

Objective: The present study aimed at providing a model to assess the competencies necessary for teachers in the Faculties of Education.

Methods: Relevant literature on the topic would be reviewed and professors, supervisors, and teachers in the general education schools would be consulted.

Results: In light of the reviews and the jury members' responses, the researchers concluded that good teacher competencies center on three main elements: Academic, Professional and Personal. The three dimensions are divided into a number of standards and under each standard there are a number of indicators; all organized in a model.

Conclusion: It is aspired that the model items will serve as a guide in the training and evaluation of prospective and in-service teachers.

Keywords: Assessment; Academic; Competence; Faculties of Education; Prospective

\section{Introduction}

We aim to develop a model, which summarizes the characteristics of successful teachers; for the improvement of teachers in the Faculty of Education. As professors and supervisors in the Faculty of Education and being associated with practical training for over twenty years; the researchers have asserted that general education schools' decision makers are not a valid assessment tool for the development and evaluation of prospective and in-service teachers. Hence, the researchers aimed to propose a model, which summarized the required teaching competencies suitable for Faculty of Education. The international and local standards were used as indicators to assess their competence.

In today's competitive world, the idea of competence has amassed significant interest. It is believed that teaching competencies can be used for guidance and in determining the qualities and personal characteristics of good teachers. Korthagen (2004, p.79) asserted that "... it is noteworthy that in many places in the world we are yet seeing the revival of a view of teaching and teacher education which focuses on competencies". Similarly, Zeichner (2010) suggested that teaching competencies should be added into the existing assessment systems for teachers and they should incorporate them in Self evaluation. Bhargava \& Pathy (2011) concluded that teaching relies on a clearly structured set of competencies among professionals employed in their respective fields; and initial teacher training programs should stress on developing those competencies to bring improvements in the education sector.

\subsection{A Global Issue}

The Competency based Model (CBM) or the Performance based Model surfaced in the middle of the Twentieth century in the field of teacher training. Many years later, studies focusing on productive processes also appeared as an attempt to determine the competencies closely related to students' learning outcomes i.e. teacher competencies. Korthagen $(2004$, p. 79$)$ noted that the main concern of CBM is that "...observable behavioral criteria could serve as a basis for the training of novices". CBTE proved to be one of the prominent features of contemporary educational 
innovations. It is believed that teacher preparation focusing on competence can help teachers in adequately performing their assigned roles. It can also help in the development of professional preparatory programs for teachers (Sulaiman, 2011). The adopted approach highlighted the roles and tasks required for an adequate determination of their skill level, knowledge and capacity (Al-Azraq, 2000). It implies that an assessment of teachers' performance can be achieved by following specific standards meant to characterize good teachers (Zainadeen, 2010; Al-Fatlawi, 2003; Becker, Kennedy, \& Hundersmarck, 2003).

Competency is defined as a set of conscious, trainable skills and abilities which make a teacher effective. Steiner et. al (2008, p. 5) stated that "Competency is a pattern of thinking, feeling, acting or speaking; which makes a person successful in a specific job or role". Research indicates that previous demonstration of competence to achieve success is one of the best predictors of future performance in a given role. Competencies may be developed, but they are most effective when used to select people who are already a good fit for the job. Naumescu (2008) asserted that in order to become competent one needs to mobilize their knowledge base and apply it in practical situations.

However, the question, which has attracted the interest of many studies, conferences and education associations are the skills and abilities needed to be mastered by effective teachers. Or, in other words, the specific skills usually practiced by good teachers which can be adopted as a model to train and evaluate novices (Benedek \& Molnar, 2012; Ramadan \& Hamza, 2011; Ilanlou \& Zand, 2011; Selvi, 2010; The British Association, 2008; The Ministry of General Education, 2006). Berry \& Ginsberg (1995) believed that establishing teacher competencies is becoming an urgent requirement for success in education.

An accurate determination of successful teacher competencies is not an easy task to accomplish; due to many reasons. It occurs due to the continuous changes around the globe in the methods and objectives of teacher training. Secondly, the difficulty in determining exactly what teachers should reflect on in their teaching to become good teachers; and the effect of psychology and other disciplines on teacher education. Korthagen (2004, p. 78) insisted that "Trying to put the essential qualities of a good teacher into words is a difficult undertaking".

The present study aims to develop and validate a model; which defines the competencies to characterize good teachers and the competencies which should be used in training teachers who graduate from Faculties of Education. Studies have proved that questionnaires can be used in assessing and developing teacher competence in specific situations i.e. the classroom (De Jong et al, 2011). The researchers reviewed both individual studies along with global conferences or symposia with a significant interest in teachers' competence. The results of the analyses indicated that names or classification given to the concept; varied in the outer level, but remained the same in content and meaning (Ilanlou \& Zand, 2011; Hong et al, 2008; Korthagen, 2004; Huntley, 2003). The researchers concluded that in spite of differences in titles and detailed characteristics, good teacher competencies center around three main dimensions i.e. Academic, Professional and Personal. The description and names of each dimension is discussed in detail in the literature section.

\subsection{Academic Competence}

Studies often differ in titles and definitions given to Academic Competence. When reviewed, one finds that they all have similar meanings and refer to a similar skill set. Hence, the crux of all academic competence studies revolves around assessing cognitive and comprehensive competence, intellectual and knowledge abilities (Ramadan \& Hamza, 2011; Ilanlou \& Zand, 2011; Mohafiza, 2009; Hong et. al, 2008, Huntley, 2003).

Academic competence includes concepts, generalizations, skills and knowledge in the teacher's field of specialization and being aware of the research methods applied in that field. Academic Competence is considered as part of a specialized competence necessary for teachers. It includes the teacher's content mastery of the subject that they teach and their cognitive and teaching comprehension competencies (Llanlou and Zand, 2011; Mohafiza, 2009). The concepts of research competence and life-long learning are also considered as vital aspects of teachers' academic competence (Benedek \& Molnar, 2012; Selvi, 2010).

International conferences and symposia support the value of academic competence and academic contexts as part of generic teacher competencies (The British Association, 2008; The Ministry of General Education, 2006). They stress on the importance of having a broad knowledge base and understanding of the taught subject (European Commission, 2013; Ministry of Education in British Columbia, 2012). Academic competence can be evaluated through the teacher's responses to the questionnaire and indicators; which prove the existence of these standards.

\subsection{Professional Competence}

Professional Competence includes the strategies of planning, methods of teaching and their implementation mechanisms. It is the application of teaching and learning theories in different learning situations and raising the 
learners' motivation to learn, encouraging them to work and using varied learning resources based on the social and psychological needs of learners.

The concept of professional competence often accounts for most of the research. It is usually mentioned by the same name with same definition and skill sets (Llanlou \& Zand, 2011; Ramadan \& Hamza, 2011) or by just listing the skills underlying professional competence which include actual teaching practices (Khazali \& Momni, 2010; Selvi, 2010; Aghai, 2006; Hasan, 2003). Professional competence is also known as vocational competence, communication and classroom competencies, scientific competence or teaching competencies (Al-Shaeb \& Zahi, 2011; Taghi Pour Zahir, 2010; Mohafiza, 2009; Shabani, 2006; Fathivajargah, 2003).

Professional competence refers to the actual teaching practices inside the classroom. It includes classroom management, knowledge on incorporating technology in teaching, curriculum planning, its implementation and facilitating the student learning process based on the learning outcomes of the course. It is the teacher's responsibility to engage students in professional learning, create opportunities for the achievement of professional knowledge and to make sure students have an adequate environment for learning (Passo \& Korento, 2010; The Department of Education and training of Western Australia, 2009). The level of professional competence can be evaluated through the teacher's response to the items on the questionnaire. The items on the questionnaire serve as an indicator to the existing standards.

\subsection{Personal Competence}

Personal competence refers to the personal qualities of a teacher. The concept has evolved from the Humanistic Based Teacher Education (HBTE). In HBTE, more attention is directed towards the student than the teacher. HBTE falls under the banner of Humanistic psychology which was introduced by Maslow in 1968.

The core element of Humanistic psychology is based on dignity; with its central purpose aimed at personal growth. Korthagen (2004, p. 79) concluded that "... the fact that this movement focused attention on the teacher was of importance to the further development of teacher education".

Personal Competence includes the personal qualities of a teacher i.e. physical health, general intelligence, good morals, linguistic ability, ability to innovate, ability to manage and take decisions and ability to communicate in the required manner with decision makers and the students' parents.

Personal Competence is often given different names. It includes the characteristics that should be available in good teachers. Personal competence involves values, attitudes, dispositions and personal effectiveness of the person (The European Commission, 2013; Taghi Pour Zahir, 2010; Mohafiza, 2009; The National Institute of Education, 2009; Shabani, 2006; Fathiviajargah, 2003). The detailed distinctive features of personal competence vital to their success include knowing the students, school, family, societal relationships, knowledge and developing better relationships with members of the learning community and learners.

At the same time, it also involves valuing and caring for all students and acting in a specified manner which best suits their interests. Acting as role models, honestly and ethically and having a good grasp on the application of knowledge on the student's development and growth. They should appreciate the support and involvement of families, guardians and parents in schools (Ministry of Education in British Columbia, 2012; Alshaeb \& Zahi, 2011; New Zealand Teachers Council, 2011; Selvi, 2010; Turkey, 2006).

\section{In Practice}

\subsection{Contemporary Trends in Teacher Education}

In today's competitive and innovative world, the field of teaching has changed drastically. The changes have been brought due to the economic, technological and cultural influences from around the globe. The changes in teacher education are primarily taking place in the developed world. Universities and colleges in the developed world are incorporating the latest innovations and methods of teaching.

A closer analysis reveals that educational institutions are evolving in fundamental ways; primarily due to the advancements in technology and easy access of information. In some cases, the orthodox methods of teaching and classroom practices have remained the same even in today's world of rapid changes.

Technology has become a vital part of education in the contemporary world. The educational curriculums are consistently improvised and relevant changes are brought to equip students with the required knowledge and skills (Hans \& Akhter, 2013). In a broader perspective, formal education experiences i.e. high test scores are considered vital in an effective teaching environment. Even today, higher marks continue to serve as a criteria for judging the 
teacher's competencies.

Teachers in the faculties of education should pave the way for students and train them in a manner that they are able to function in their complex technological futures. Hence, teachers and educators need to be equipped with the technological advancements and their incorporation in teaching. Prospective teachers who enter the profession need thorough training and guidance. Relevant models are used across the world to train teachers and to educate them on the contemporary methods of education. An issue arises when teachers continue to teach in the manner they were taught. Today, educationists realize the importance of meeting the innovative and digital demands of teaching.

\subsection{Technology \& Contemporary Teaching Methods}

Incorporating technological methods in teaching implies that both the teacher and the student have the right tools and are equipped with the essentials to teach and learn properly. A broad range of digital collaborative methods is employed by teachers to educate their students. The younger students who have grown up in the digital age cannot be taught by using the orthodox methods of classroom teaching.

In today's world, education is given vital importance and research is being conducted across the world on effectively training teachers. Video conferencing, Internet instant messaging and networks form a major part of today's teaching trends. Orthodox education systems are not always effective and tend to have a negative impact on the learning of students. Hence, key components need to be addressed in the assessment of all teachers' education programs i.e. the skills and proficiency of teachers, their familiarity with technology and their knowledge and skill level in the field.

Due to the issues in assessing teacher competencies, a professional collaboration between general school teachers, professors, supervisors and school administrators is needed. Experts in the field are continuously looking to improve the teaching standards and to improve the professional credibility of teachers. Positive changes in teacher training programs would not only ensure quality education, but would also improve the overall understanding of students. Governments should take the initiative and introduce teaching practices used in urban settings to rural areas as well. Emerging trends among teachers are more content focused and include multimedia, networks and computer based instruction. Such teaching trends allow prospective teachers to review case studies and pick up newer modes of instruction to improve their lectures.

\section{Research Notice-Board}

The idea of teacher competency has gained momentum over the past decade. An adequate assessment of teacher competencies is vital to improving the standard of education. The faculties of education in universities realize its importance. A number of studies are being conducted to develop models of teacher competency assessment (Steiner, 2013). Universities across the globe realize the importance of developing effective models for assessment of teacher competencies.

An analysis reveals of teacher education programs across the United States reveal that a good set of skills are required to effectively teach a diverse population of students. The subjects taught in the faculty of education require teachers to have a good grasp on the subject. Due to the advancements in technology, student familiarity with networks, computers and instant messaging has increased. Teachers in the faculties of education are required to adopt these technological advancements. By doing so, teachers can make their lectures interesting. It also induces the desire to learn among students (Blanton, Griffin, Winn, \& Pugach, 1997)

A vast number of studies are being conducted on developing models and tools to assess teacher competencies. Also, training new teachers is vital to ensuring quality education. The faculties of education around the world realize its importance and are allocating sufficient funds to ensure research in the field.

\section{Methodology}

The present study involved a descriptive analytic study conducted between the period of September and December 2013. One instrument was used in the research namely a model including the necessary competencies of good teachers.

1. The model was divided into three main dimensions that were deduced from local and global studies, conferences, and symposia on teachers' competence and by obtaining responses of jury members.

2. Each dimension included a number of standards associated with the appointed dimension.

3. Each standard was subdivided into a number of indicators which were used to judge the achievement of that standard. 
The content validity of the model items was measured by seeking the evaluation of Eighty (80) jury members including teachers and supervisors from general education schools and professors at Faculties of Education. To avoid neutral answers, a three-point Likert scale i.e. $(1=$ not at all important, $3=$ very important $)$ was used against each item of the model. All participants enclosed their desired responses in a separate form. Based on the suggestions of the participants, the model items were modified and substituted until they reached their final form.

The reliability of the model items was established through the test-retest process. The model was transferred into a questionnaire form and was administered twice on a sample of (12) teachers. The two applications were done a week apart. The Pearson Correlation Factor was applied on the responses in the first and second application. The value ranged between (0.78), (0.93) and (0.82). For the model dimensions see table (1).

Table 1. Internal Consistency of the Model Dimensions

\begin{tabular}{ll}
\hline Dimension & Correlation Factor \\
\hline Academic & 0.78 \\
Professional & 0.93 \\
Personal & 0.82 \\
\hline
\end{tabular}

\section{Results and Discussion}

After a careful analysis of the participant responses and reviewing relevant literature on assessing competence of teachers in the faculties of education; certain inferences were drawn. The indicators included all standards of academic competence through which teacher competency can be assessed see table (2)

Table 2. Standards and Indicators of Academic Competence

\begin{tabular}{|c|c|c|}
\hline \multicolumn{3}{|c|}{ Academic Competence } \\
\hline No & Standards & licators \\
\hline 1 & Mother tongue proficiency & $\begin{array}{ll} & \text { Mastering mother tongue } \\
\text { - } & \text { Pronunciation clarity } \\
\text { - } & \text { Reading proficiency of scientific content } \\
\text { Writing proficiency with no spelling mistakes }\end{array}$ \\
\hline 2 & $\begin{array}{l}\text { Mastering basic Numerical and } \\
\text { Geometrical Skills }\end{array}$ & $\begin{array}{l}\text { - } \quad \text { Reading numbers and digits correctly } \\
\text { - } \quad \text { Kerforming the four basic operations skillfully } \\
\text { - } \quad \text { Knowing the value of each digit in a number } \\
\text {. }\end{array}$ \\
\hline 3 & $\begin{array}{l}\text { Mastering at least one foreign } \\
\text { language }\end{array}$ & $\begin{array}{l}\text { - Reading related articles in the foreign language } \\
\text { - Writing in correct spelling } \\
\text { - Reviewing literature related to one's subject in the } \\
\text { foreign language }\end{array}$ \\
\hline 4 & $\begin{array}{l}\text { Proficiency in own subject and } \\
\text { teaching it according curriculum } \\
\text { objectives }\end{array}$ & $\begin{array}{l}\text { - Analyzing the scientific content of one's subject } \\
\text { (concepts-generalizations-skills) } \\
\text { - Defining educational objectives of each unit in the } \\
\text { syllabus } \\
\text { - Defining prerequisite knowledge of the subject } \\
\text { - Joining pre-knowledge with present knowledge }\end{array}$ \\
\hline 5 & $\begin{array}{l}\text { Achieving integrity through } \\
\text { subjects. }\end{array}$ & $\begin{array}{l}\text { - Joining knowledge and information of one's subject } \\
\text { with other subjects } \\
\text { - Presenting one's subject as a social culture } \\
\text { - } \quad \text { Encouraging students to transfer knowledge to real life } \\
\text { content }\end{array}$ \\
\hline
\end{tabular}


$6 \quad$ Awareness of recent content related to one's subject

$7 \quad$ Application of scientific research skills
- Familiarity with recent content in one's subject

- Integrating information and communication technology in education

- Motivating students to be creative and innovative

- Varying teaching methods to account for individual differences (Intelligence -capabilities-Preference).

- Mastering methods of modern evaluation

- Participate in workshops related to one's subject

- Use and employ ideas in scientific articles to improve one's subject

- Determine resources suitable for one's subject

- Motivate students to read and research continuously

- Use research methods for self and continuous learning in one's subject

Indicators underlie each standard of professional competence through which teacher competency can be assessed see table (3)

Table 3. Standards and Indicators of Professional Competence

\begin{tabular}{|c|c|c|}
\hline \multicolumn{3}{|r|}{ Professional Competence } \\
\hline No & Standards & Indicators \\
\hline 1 & $\begin{array}{l}\text { Planning lessons } \\
\text { according to suitable } \\
\text { teaching strategies }\end{array}$ & 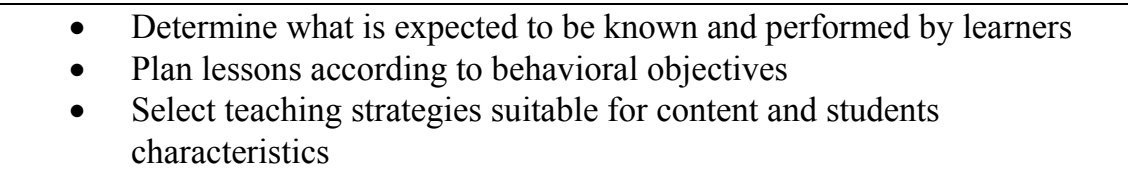 \\
\hline 2 & $\begin{array}{l}\text { Implementation of } \\
\text { lessons and classroom } \\
\text { management }\end{array}$ & $\begin{array}{l}\text { - Apply suitable teaching strategies according to content and students' } \\
\text { characteristics } \\
\text { - } \quad \text { Leads seminars } \\
\text { - Apply strategies of discovery, survey, and active learning which } \\
\text { - } \text { Apcourage thinking and creativity } \\
\text { - } \quad \text { Use technological and educational techniques to strengthen one's } \\
\text { - } \text { teaching skills and facilitate the process of learning } \\
\text { - } \text { Organize the learning environment in the classroom in a way that } \\
\text { - } \text { Oreassures tranquility and induces feelings of security among students } \\
\text { - Use suitable teaching strategies that take into account individual } \\
\text { - } \text { differences } \\
\text { Present activities that are suitable to different levels (gifted, normal, } \\
\text { learning difficulty student) } \\
\text { Use suitable reinforcement methods according to different abilities of } \\
\text { students }\end{array}$ \\
\hline 3 & $\begin{array}{l}\text { Using modern evaluation } \\
\text { methods }\end{array}$ & $\begin{array}{l}\text { - Use pre-evaluation of information related to new knowledge } \\
\text { - } \quad \text { Use varied evaluation methods suitable to behavioral objectives of the } \\
\text { - } \quad \text { Usject } \\
\text { - } \quad \text { Evaluate students through meaningful and authentic situations } \\
\text { - } \quad \text { Apply diagnostic and summative evaluation } \\
\text { - } \quad \text { Assign suitable and enough time for evaluation } \\
\text { - } \quad \text { Contribute to the evaluation of the educational process and its elements }\end{array}$ \\
\hline
\end{tabular}

Indicators underlie each standard of personal competence through which teacher competency can be assessed see table (4) 
Table 4. Standards and Indicators of Personal Competencies

\begin{tabular}{|c|c|c|}
\hline \multicolumn{3}{|c|}{ Personal Competence } \\
\hline No & Standards & Indicators \\
\hline 1 & $\begin{array}{l}\text { Having good appearance and healthy } \\
\text { body }\end{array}$ & $\begin{array}{ll}\text { - } & \text { Taking care of outward appearance } \\
\text { - } & \text { Voice clarity and correct pronunciation } \\
\text { - } & \text { Physical health }\end{array}$ \\
\hline 2 & $\begin{array}{l}\text { Believing in values and principles of } \\
\text { the society one belongs to }\end{array}$ & 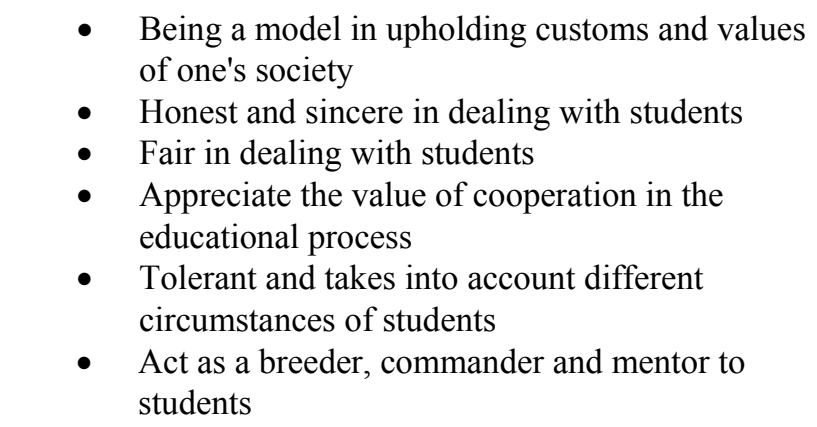 \\
\hline 3 & $\begin{array}{l}\text { Having sound psychological } \\
\text { characteristics }\end{array}$ & 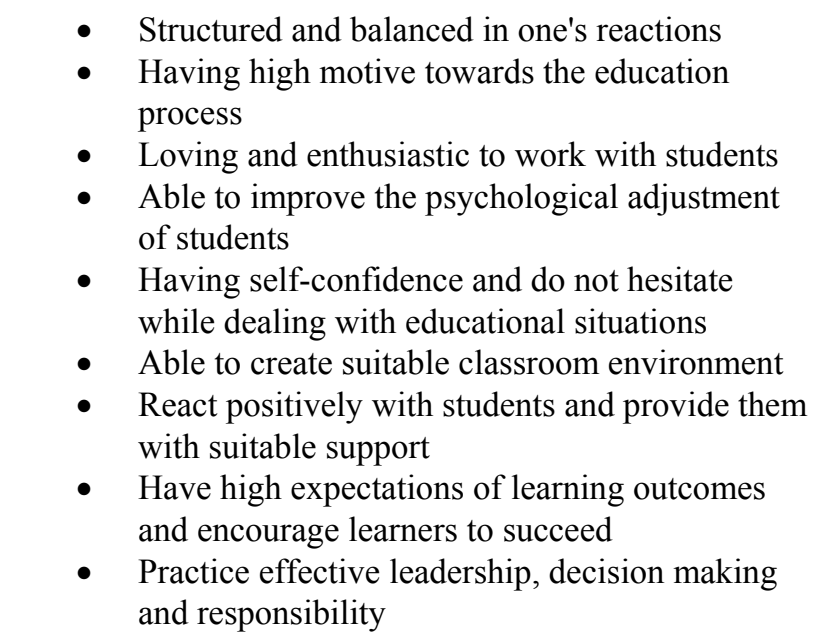 \\
\hline 4 & $\begin{array}{l}\text { Ability to communicate effectively } \\
\text { with all people involved in the } \\
\text { educational process and with parents }\end{array}$ & $\begin{array}{l}\text { - Attract students, make them confident and } \\
\text { accept teachers' directions } \\
\text { - } \quad \text { Flexibility and coping with different situations } \\
\text { - } \\
\text { - } \\
\text { Colerance and accommodate others } \\
\text { involved in the educational process } \\
\text { Continuous communication with parents and } \\
\text { informing them with everything happen in the } \\
\text { classroom } \\
\text { Work in groups and cooperate positively with } \\
\text { colleagues and stakeholders inside and outside } \\
\text { school }\end{array}$ \\
\hline
\end{tabular}

\section{Conclusion}

All in all, the model was developed to be used as a guide in determining the required competencies for the evaluation and development of teachers in the Faculty of Education. The model can be used in the evaluation of preparatory programs of general education teachers. It can also allow an accurate assessment of academic indicators i.e. personal competencies.

The model can also prove to be helpful in assessing the availability of the standards and indicators of academic, professional and personal competencies among general education teachers in schools and in the summative 
evaluation of prospective teachers who graduate from the Faculties of Education. Some modifications can be made in teacher preparation programs under the light of the suggested model i.e. the employment of education technology in different fields of specialization and life-long learning to cope with educational changes. New teacher preparatory programs can be designed to fulfill the required characteristics of good teachers and to raise their competence.

\section{References}

\section{English Works Cited}

Aghai, A. (2006). Recognition of personal and professional features of future teachers (MA thesis). Tahran: Shahed University.

Becker, B., Kennedy, M., \& Hundersmarck, S. (2003). Hypothesis about 'quality': A decade of debates. Paper presented at the annual meeting of the American Educational Research Association.

Benedek, A., \& Molnar, G. (2012). Development of teacher competencies in a new learning environment in higher education. The seventh international multi-conference on computing in the global information technology. Hungary

Berry, B., \& Ginsberg, R. (1995). Effective schools and teacher professionalism: education policy at crossroads' in Bliss et al. Rethinking Effective School: Research and Practice. Prentice-Hall. Englewood Cliffs, NJ.

Bhargava, A., \& Pathy, M. (2011). Perceptions of student teachers about teaching competencies. American Educational Journal of Contemporary Research, 1(1), 77.

Blanton, L. P., Giffin, C. C., Winn, J. A., \& Pugach, M.C. (1997). Teacher education in transition: Collaborative programs to prepare general and special educators. Denver, CO: Love Publishing Co. Retrieved from http://www1.chapman.edu/ITE/dingle.pdf

British Association of Lecturers in English for Academic Purposes. (2008). Competency framework for teachers of English for Academic Purposes. Retrieved from www.baleap.org.uk

British Columbia Ministry of Education. (2012). Standards for the Education, Competence and Professional Conduct of Educators in British Columbia. Fourth Edition.

Department of Education and Training. (2004). Competency Framework for Teachers. Government of Western Australia.

European Commission: Education and Training. (2013). Supporting teacher competence development, for better learning outcomes.Retrieved from http://ec.europa.eu/education/school-education/teacher-cluster_en.htm

Fathivajargah, K. (2003). Standard School. (7rd ed). Tehran: Fakher.

General Directorate of Teacher Training. (2006). 'Teacher Training Competent: Generic Teacher Competencies'. Support to Basic Education Project (SBEP). Turkish Republic Ministry of National Education.

Hans, A., \& Akhter, S. (2013). Emerging trends in teacher's education. The Macrotheme Review. Special Issues on Education \& Training. pp. 26-27.

Hong. J., Shyan Horn, J., Li Lin, C., \& Juan ChanLin, L. (2008). Competency disparity between pre-service teacher education and in-service teaching requirements in Taiwan. International Journal of Educational Development, 28(1), 4-20.

Huntley, H. (2003). Teachers' work: beginning teacher. Conceptions of Competence'. Thesis, Central Queensland University.

Ilanlou, M., \& Zand, M. (2011). Professional Competencies of Teachers and the Qualitative Evaluation. Procedia Social and Behavioral Sciences, 29, 1143-1150.

Korthagen, F. (2004). In search of the essence of a good teacher: towards a more holistic approach in teacher education. Teaching and Teacher Education, 20, 77-97.

Maslow, A. (1968). Toward a psychology of being ( $2^{\text {nd }}$ ed). Princeton, NJ: Van Nostrand.

Naumescu, A. (2008). Science teacher competencies in knowledge based society. ActaDidacticaNaposencia, 1(1), 25-31.

New Zealand Teachers Council Ministry of Education. (2011). Tataiako-cultural competencies for teachers of Maori learners. A resource for use with the Graduating Teachers Standards and Registered Teacher Criteria. 
Passo, A., \& Korento, K. (2010). The Competent teacher 2010-2020: The competencies of teaching staff in upper secondary vocational education and training. Final Report OULU Vocational College. Finnish National Board of Education.

Schaub-de Jong, M. A., Mirabelle, A., Dekker, J. Hanke, V., \& Marian \& Cohen-Schotanus, M. J. (2011). Development of a student rating scale to evaluate teachers' competencies for facilitating reflective learning. Medical Education, 45, 155-156.

Selvi. K. (2010). Teachers' competencies. CULTURA, 7(1), 167-175.

Shabani, H. (2006). Educational skills. Tahran: Samt publications.

Steiner, L. (2013). Using competency based evaluation to drive teacher excellence. public impact. Retrieved from http://opportunityculture.org/images/stories/singapore_lessons_2010.pdf

Steiner, L. et al (2008). School turnaround teachers: competencies for success, Part from the School Turnaround Collection from Public Impact. For the Chicago Public Education Fund. June. Retrieved from www.Publicimpact.com

The National Institute of Education. (2009). A Teacher education model for the $21^{\text {st }}$ century. A report by: The National Institute of Education. Singapore.

Zeichner. K. (2010). Preparing globally competent teachers: A U.S. perspective'. 2010 colloquium on the internationalization of teacher education. NAFSA: Association of International Educators. University of Washington. Seattle.

\section{Arabic Works Cited}

$$
\begin{aligned}
& \text { الأزرق، عبدالرحمن (2000) "علم النفس التربوي للمعلمين"، ط1، مكتبة طر ابلس العلمية العالمية: طر ابلس }
\end{aligned}
$$

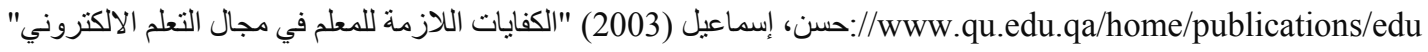

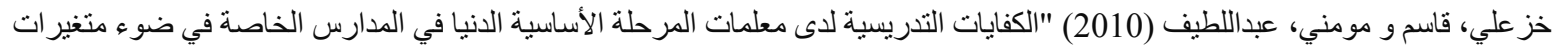

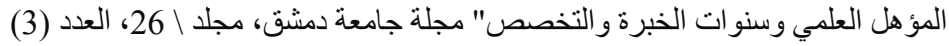

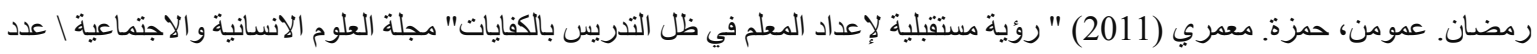

$$
\begin{aligned}
& \text { خاص: ملتقى التكوين بالكفايات في التربية } \\
& \text { زين الدين ، محمد (2010): أدوار جديدة للمعلم مع.. التعليم الإلكتروني، مجلة المعرفة }
\end{aligned}
$$

http://www.almarefh.net/show_content_sub.php?CUV=375\&Model=M\&SubModel=140\&ID=740\&ShowAll=On





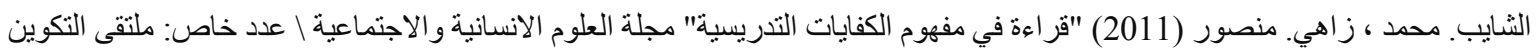

$$
\begin{aligned}
& \text { بالكفايات في التربية } \\
& \text { الفتلاوي. سهيلة (2003) "كفايات التدريس: الدفهوم، التدريب، الأداء"، عمان، دار الثروق }
\end{aligned}
$$

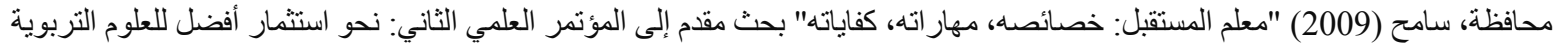

$$
\begin{aligned}
& \text { و النفسية في ضوء تحديات العصر المنعقد في رحاب جامعة دمشق كلية التربوية في الفترة من 2009/10/27- }
\end{aligned}
$$

